\title{
(Im)politeness and Emotion in Academic Correspondence
}

\author{
Juan Antonio Caldero \\ Faculty of Business and Law, Coventry University, UK
}

Lin Sun

School of Foreign Languages, Southwest University of Political Science and Law, China

\begin{abstract}
Wechat and email are the principal platforms of online interactivity in academia. Lack of English language pragmatism and the transfer of polite requests from L1 into L2 might have the outcome of perception of (im)politeness. Speakers might encounter issues distinguishing between orders vs. want i.e. requests. A certain adherence to the pragmatic clarity of the message is an essential part of inferring (im)politeness. (Im)politeness could be addressed as communication strategy with the main purpose of (breaking)maintaining relations between the interlocutors. In academic correspondence both the use of direct and non-conventional indirect strategies by Chinese students' positive politeness might be inferred as impolite by British academics' negative politeness. This research shows how Chinese L2 English's academic correspondence might lead to the emotion of mild irritation triggered by the reader's inferring of (im)politeness; therefore, an intended degree on (im)politeness requires an appropriate level of pragmatic competence in $\mathrm{L} 1$.
\end{abstract}

Index Terms - academic correspondence, requests, positive politeness, negative politeness, pragmatic failure

\section{INTRODUCTION}

According to China-Britain Business Council (2019) the demand for joint courses in specialist areas continues to grow in China. Moreover, the number of Chinese graduates applying to British universities is also on the rise. Universities have increased the number of programmes and partnerships between these two countries. The UK has incorporated SINO-UK programmes through innovative collaboration with Chinese partners, joint-research programmes, and two-way staff and student exchanges, including those linked with industry.

The SINO-UK programmes main characteristic is the use of English as their vernacular language. The expansion of British Universities into China goes alongside the spread of the English language with exceeds that of any other language (Culpeper, 2012, p. 1128). These programmes have increased the need for information about the nature of students' (im)politeness in their academic correspondence. Very little empirical investigation has taken place regarding the academic communication sent by students during their university education (BiesenbachLucas 2004). Previous interlanguage research on email requests (Hartford and Bardovi-Harlig, 1996; Biesenbach-Lucas, 2007; EconomidouKogetsidis, 2011; Félix-Brasdefer, 2012; Pan, 2012) indicates that, despite the learners' high L2 proficiency, they may often lack adequate pragmatic awareness and competence in L2 email writing (Biesenbach-Lucas, 2004, 2007; Chen, 2006; Economidou-Kogetsidis, 2011) resulting in status-incongruent messages capable of pragmatic failure.

The majority of Chinese learners of L2 English might not receive sufficient input on pragmatic competences to learn the basics of academic writing correspondence i.e. students begin their academic journey based on rules and principles of general English. The outcome might be lack of politeness in academic communication between Chinese learners of L2 English and their British lecturers. The study shows that Chinese students of L2 English use positive politeness strategies in their academic correspondence. It demonstrates how learner's perception of politeness is linked with their positive politeness strategies, triggering the emotion of mild irritation in negative politeness' readers.

The data discussed here are from academic correspondence between Chinese learners of L2 English and Coventry University academic members of staff. The methodology will focus on action research based on the idea of a reflective process to solve an immediate problem by individuals working in their own practices (McKernan, 1991a). Action research is an effective way of enhancing both academic and learners' performance in a particular task to change and offer new alternatives. This work does not advocate a change but an adaptation in which learner might use strategies to understand way of politeness that might be completely alien to them. The findings would have implications for L2 learners to acknowledge the interlanguage pragmatics and to have the choice of choosing between positive or negative politeness in their academic writing.

\section{Positive AND Negative Politeness}

What makes interesting to analyze on-record strategies in academic correspondence is the way "interactions are associated [...] with elevated addressees" (Brown \& Levinson, 1987, p. 12), in other words, on-record requests are 
linked to specific linguistic and grammatical forms, making it visible to be identifiable in learners' academic correspondence.

According to Brown \& Levinson, on-record requests are "face-threatening acts". In academic communication, requests are mainly the main reason for learners to send an email to their lecturers. Through the speech act of request, speakers expect the hearer to do an action that would be only beneficial to the speaker and costly to the hearer. According to Brown \& Levinson "some speech acts such as direct and non-conventional indirect speech are intrinsically face threatening" (Brown\&Levinson,1987, p. 59). Meanwhile, individuals will try to assess the situation during their interactions and decide how to perform the Face Threatening Act (FTA). Brown \& Levinson clearly explain the process to calculate the FTA:

$$
\mathrm{W}_{\mathrm{x}}=\mathrm{D}(\mathrm{S}, \mathrm{H})+\mathrm{P}(\mathrm{H}, \mathrm{S})+\mathrm{R}_{\mathrm{x}}(\text { Brown \& Levinson, 1987, p.76) }
$$

Where $W_{x}$ is the weightiness of the FTA $A_{x}(S, H)$ is the social distance between $S$ and $H, P(H, S)$ is the power that $H$ has over $S$, and $R_{x}$ is the degree to which the FTA is rated as an imposition in the given culture in which $S$ and $H$ are situated.

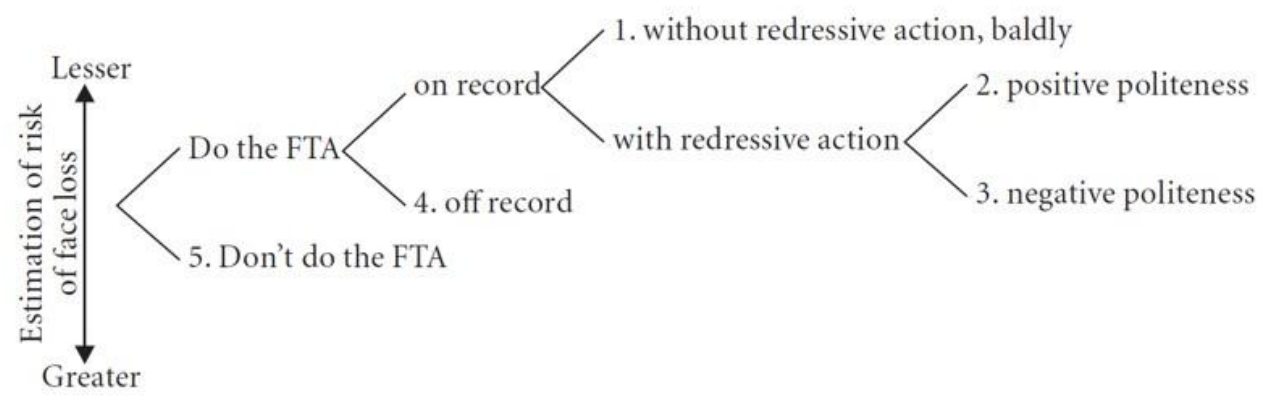

Fig. 1 Strategies for performing FTAs (Brown\&Levinson, 1987, p. 60)

In the event that the speech act has no or very little weightiness, it can be produced baldly, on record, without any redressive action. This can be seen on some of the Wechat ${ }^{1}$ Academic correspondence students sent to lectures. Example (1) shows that students' Wechat message could be inferred as demanding or even aggressive.

(1) Hi Juan, I sent you an email. Check it

Moreover, the Co-operative Principle and its maxims are based on the assumption that the primary purpose of a conversation is the "maximally effective exchange of information" (Grice, 1989, p. 28). Grice's Maxims, specifically the maxims of manner, could influence learners' use of positive politeness in their academic correspondence (Figure 2).
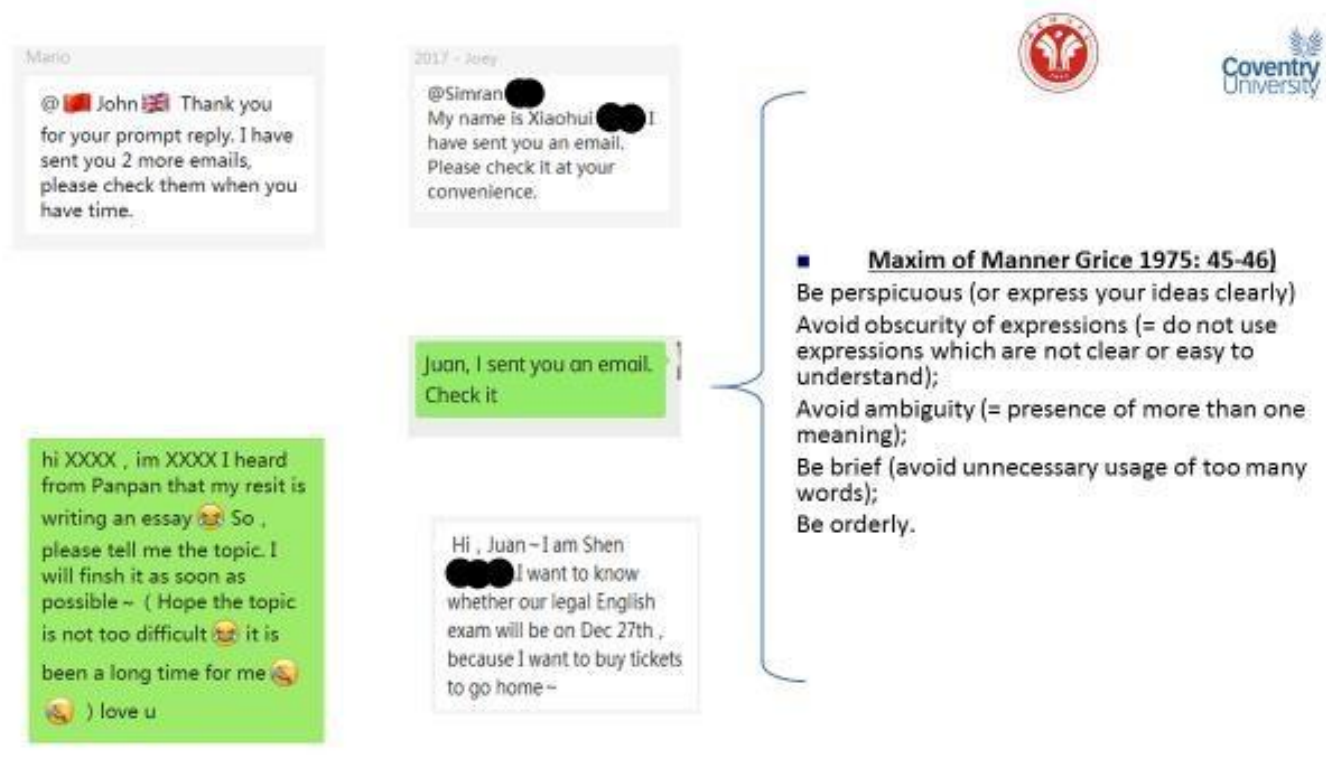

Fig. 2 Politeness and the Maxims of Grice

Example (1) illustrates Brown \& Levinson's bald on record strategy (Brown \& Levinson, 1978, p. 74).

This strategy shows a direct request without redressive action. When it is combined with the Maxim of Manner, it would offer a direct, clear, unambiguous and concise way of requesting.

\footnotetext{
${ }^{1}$ Wechat is a widely used Chinese social media platform. 
This maxim emphasizes clarity under the guidance of which Chinese learners of L2 English could imply to minimize the distance between the speakers; however, for British academics the same samples might be inferred as rude or impolite as (2) shows:

(2) Dear xxx,

Could you explain things clearly and straightforward when you send out an email. It really confused me almost every time.

Please explain clearly as which cohort, which module and when the exam is taking please, don't let us to guess!

And you need to give me at least one week to print out the exam paper before the exam taking place.

Best wishes,

Brown \& Levinson (1987) claim that the primary reason for bald on record usage would be whenever the speaker wants to do FTA with maximum efficiency. That is, in order to satisfy the hearer's face, the speaker will select a bald on record strategy.

\section{A. Negative Politeness}

Leech (1983) refers negative politeness as "indirect illocutions tend to be more polite (a) because they increase the degree of optionality, and $(b)$ because the more indirect the illocution is, the more diminished and tentative its force tends to be" (Leech, 1983, p. 108). That is, Leech shows that the speaker could try to save face by increasing concern for the addressee. Moreover, Lakoff (1973) argues that most indirect strategies are used in formal context; whereas least indirect might be used between intimates and friends; Brown \& Levinson (1987) discuss that the greater the threat to face, the more indirect strategy the speaker would choose (Fig. 1).

Brown \& Levinson state that the more indirect the utterance is the more polite will be; in other words, the degree of politeness is proportional with the degree of indirectness. However, "increased indirectness can also result in impoliteness" (Brown \& Levinson, 1987, p. 82) as the example illustrates:

"I must really ask you to be a little quieter, said Holmes severely. You have already imperiled the whole success of our expedition. Might I beg that you would have the goodness to sit down upon one of those boxes, and not to interfere? (Doyle, 2007, p. 80)

Brown \& Levinson negative politeness is a redressive action addressed to the addressee's negative face. The authors describe negative politeness as the predominant behavior of Western

cultures, being "the most elaborate and most conventionalized set of linguistic strategies for FAT redress" (Brown \& Levinson, 1987, p. 130). That means that negative politeness - and its claim to freedom of action and freedom from imposition - would be the set of linguistic politeness that Westerns academics would use in their academic correspondence.

In case readers want to have freedom of action, their perception of politeness would be directed related to the avoidance of directness. Brown \& Levinson states that "it [negative politeness] is the heart of respect behaviour, just as positive politeness is the kernel of 'familiar' and 'joking' behaviour" and 'it [negative politeness] performs the function of minimizing the particular imposition that the FTA unavoidably effects” (Brown \& Levinson, 1987, p. 129). Likewise, it could be argued that some Chinese learners of L2 English might prefer the use of 'familiar' behavior in their academic communication. Some learners in relation to (1-3), (5-9) and (Fig.1) pointed out comments such us: "why lecturers have to get offended by my email when I treat them like family" [...] "are you telling me that they are also polite with their children and friends?"

Negative politeness is generally used for social 'distancing'; i.e. this linguistic strategy can be associated with the need of social brake when necessary during the interaction. However, learners of L2 English might lack pragmatic linguistic competence with the outcome that learners' academic correspondence might be inferred as impolite or rude (2)-(3) by the reader.

(3) Hi Juan. I am Shen xxxx. I want to know whether our legal English exam will be on Dec $27^{\text {th }}$, because I want to buy tickets go home.

(2 - 3) show how Chinese learners of English L2 transfer their L1 positive politeness strategies into their L2 pragmatic competences.

\section{B. Positive Politeness ${ }^{2}$}

Brown \& Levinson (1987) show that imperatives are often softened with conventional politeness markers (2). In addition, the bald imperative (1) might appeared alongside the Gricean maxims (Fig. 2). Positive politeness in negative

\footnotetext{
${ }^{2}$ In addition to use positive politeness in academic correspondence, there are other factors that according to Steve Foster (2013) might "irritate the marker". "Lecturers do appreciate good grammar, spelling and style and are very often irritated by poor writing skills" - "Many students submit work with countless spelling and typographical errors. This is unprofessional, creates a poor impression and irritates the marker" Due to time restriction this has not been analysed however, it might have an influence on triggering lecturers' mild emotion of anger.
} 
politeness cultures might be acceptable within friends or in social situations when people they know each other fairly well. However, even within the familiar circle, positive politeness might not be the safest way of making a request. Michael Haugh, during the International Symposium on Advance in (Im)politeness Studies in Fuzhou - Fujian, perfectly described it when he commented (4):

(4) "Even though I know about politeness I still find it difficult to tell my children 'take the rubbish out'.

This sample shows that individual emotions in negative politeness environments are set on speakers rather than the listeners. The speaker is convinced that using positive politeness strategies will trigger the hearer's mild irritation of anger. More importantly, the speaker expects to be addressed in the same way. However, this conviction of applying the speakers' negative politeness universally might cause friction or even tension within positive politeness societies.

In positive politeness societies such as China, the same context on bald request "take the rubbish out" would have been perfectly acceptable by both the speaker and the listener. Likewise, in positive politeness' contexts, the speaker's inner emotions towards the listeners would have not implied mild irritation of anger but rather closeness and friendship.

However, when Chinese learners of L2 English acquired negative politeness' pragmatic competence it could be referred as temporary rather than permanent. As (4) implies that in Western societies negative politeness is permanently fixed in individuals' linguistic behavior alongside with the emotion of mild irritation.

Researchers have found that teaching children specific forms of politeness could be considered a major source of politeness' input that children will receive. This input will permanently adapt into children's linguistic cognitive behavior; (Snow et al., 1990, p. 235) illustrate this:

(5) Father: Say 'please could I have some ketchup'. Child: Please.

Father: Please may I have some ketchup.

Child: Please.

Father: Just say the whole sentence for a change: Please may I have some ketchup. Child: Please.

Father: No. We're gonna wait till you say, 'Please may I have some ketchup.' Child: Please can I have the ketchup.

(4-5) demonstrates that it would be complex for negative politeness individuals to utter positive politeness on bald record request. This might be due to the speaker's conviction of triggering the emotion of mild irritation in the hearers' cognitive thought. However, Chinese learners of L2 English might not have the conviction of triggering the readers' mild irritation. That is, learners might find acceptable to use positive politeness strategies in request speech acts.

Equally, Brown \& Levinson do not argue that positive politeness individuals might need shorter specific periods of adaptation to minimize $\mathrm{D}(\mathrm{S}, \mathrm{H})$ between the interlocutors than negative politeness individuals might. That is the acquisition of negative politeness in learners of L2 English might not be permanent but rather temporary complementing (4) their pragmatic competences.

(6) Dear Juan,

I am xxxx. Have you ever checked the email from LSE? I have filled in your personal information as referee. Would you like to help me submit the letter of recommendation?

If you have any problem, please let me know.

Thanks a lot in advance!

Best of luck,

(7) Dear Mr.Juan,

Excuse me,I am xxx xxx from class 10. Because i had lost my identification and bank card last week, i have to reapply them in my hometown during this holiday. And i am afraid that it could not be completed until Oct.9.So $i$ could not attend the Academic English on monday.

I have already apply for admission from my tutor. Hope you can understand. Have a good day!

(8) DearJuan,

This is $\mathrm{xxx} \mathrm{xxx}$ from team three. I'm sorry to tell you a bad news. Because the classmate's physical condition has a problem, I will accompany her to go to the hospital to do the examination tomorrow morning. The hospital is far away from the school, so I probably won't be able to make it back before the third group starts classes tomorrow. So I want to ask you for a leave and ask for your permission. I will try my best to come back in the afternoon.I will have classes with other groups. Hopping to get your understanding. Wish you a happy new week!

(9) Hello Mr.Juan,

Hope you have a good time recently!

Sorry to bother you again. I have written a new personal statement which briefly introduces my performance in xxxx.

I really love you and your Legal English course. Therefore, please! I really want a reference letter from you, my excellent teacher. Could you please help me again? I would be really grateful for that! Best wishes, xxx

L2 researchers (Blum-Kulka \& Olshtain, 1984; Fukushima \& Iwata, 1985; Meier, 1997) found that a variety of situational factors (e.g., familiarity, or gender) played important roles in the use of politeness strategies in requests. (6-9) show how Chinese learners create a close requester-requestee relationship both socially and psychologically. Once the relationship develops learners might perfectly choose on bald record strategies (1) i.e. learners might prefer, as the 
relationship builds, use the imperative mood as linguistic positive politeness strategy in their academic correspondence (10-11).

(10) Dear Juan:

I am not sure if I have copied the mail which I have sent to Tony few minutes ago to you yet. I am not familiar with this system. Tell me whether you have received my mail or not

Thanks a lot!

(11) Dear Juan

I'm sorry to bother you, but after I sent an email to Simran yesterday afternoon for my essay, she hadn't answered me yet. I don't know if there is any problem with my email. Contact her to check my email for me?

Chinese learners of L2 English might transfer their L1 politeness into L2. Figure 3 illustrates the use of positive politeness in academic correspondence between Chinese learners and their Chinese lecturers. The context of these correspondence examples is the submission of learners' assessments. Figure 3 demonstrates closeness and friendly relation between lecturers and learners.
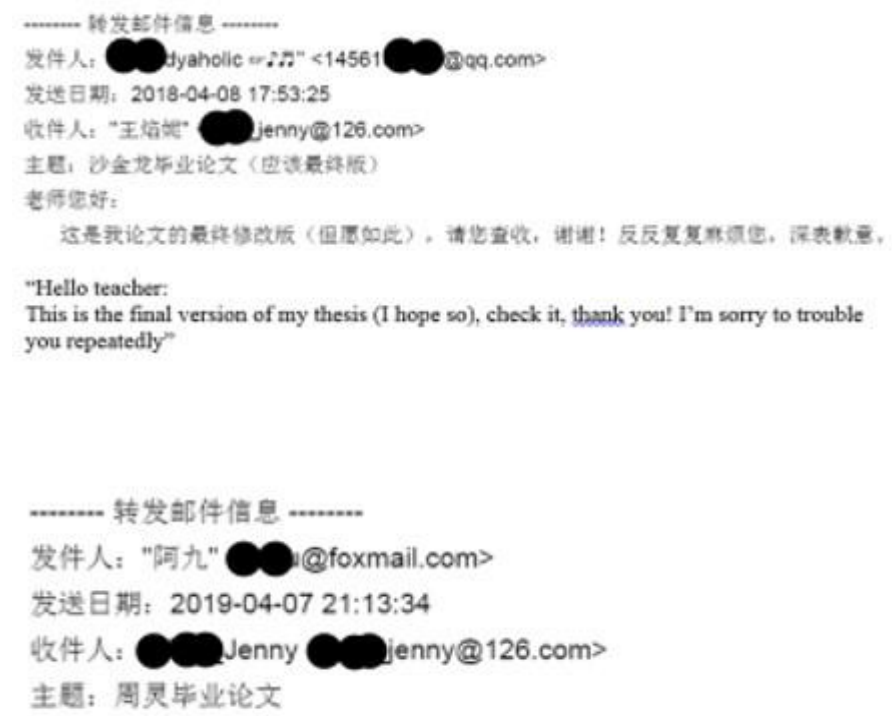

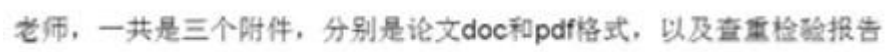
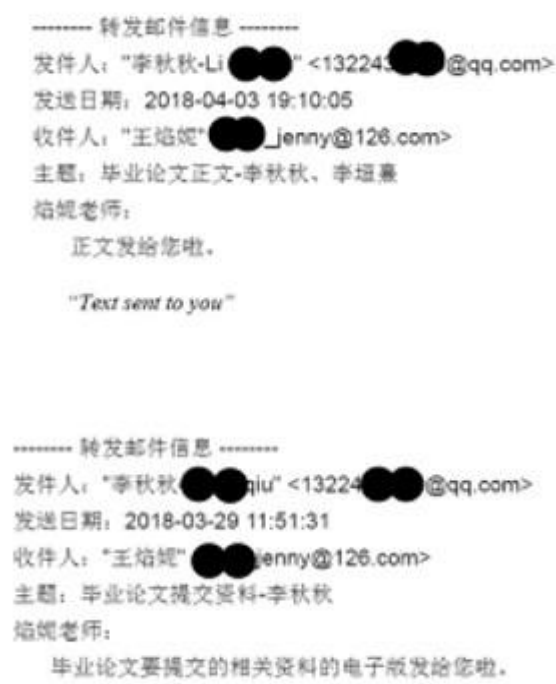

-I sent you the electronic of the gradhation thesis relevant data"

Teacher, there are three artachments, the paper doc and pdf formak, and the retest report

Fig. 3 Academic correspondence between Chinese learners and Chinese lecturers

Brown \& Levinson (1987) state positive politeness as "the want of every member that his wants be desirable to at least some others" (Brown \& Levinson, 1987, p. 61). In other words, positive politeness is redress directed to the hearer's positive face. They show that linguistic realization of positive politeness tends to be normal linguistic behavior between friends and peers $(10-11)$. This is indicated by "presupposition indicating shared wants and shared knowledge".

This indicates that the reader uses positive-politeness techniques in order to decrease social distance. In other words, students' academic requests could be linguistically connected with those requests address to family or friends in which is not necessary to be polite.

In academic correspondence, learners should avoid possible references to the readers' wants. Example (12) illustrates learners' praises emotions and feelings towards their lecturer: "I really love you..."; learners' keep reminding lecturers about their great job teaching them "my excellent teacher". In other cases, learners' correspondence might be inferred as demanding and directive "I really want a reference letter from you". The writer minimizes the distance between her and the reader "I really love you" consolidating the requester-requestee relationship and identifying it as friendly or familiar as observed in $(10-11)$. Constant repetition of the same patterns, structures and contents might trigger lecturers' mild irritation of anger.

(12) Hello Mr.Juan,

Hope you have a good time recently!

Sorry to bother you again. I have written a new personal statement which briefly introduces my performance in SWUPL.

I really love you and your Legal English course. Therefore, I really want a reference letter from you, my excellent teacher. Could you please help me again? I would be really grateful for that!

\section{C. (Im)politeness and the Emotion of Mild Irritation}


There is no solid agreement in what 'impoliteness' actually is. Locher \& Bousfield (2008) state that "impoliteness is behavior that is face-aggravating in a particular context"

(Locher \& Bousfiled, 2008, p. 3). Lakoff (1973) argues that "[impoliteness] can only almost plausibly be interpreted as intentionally and negatively confrontational" (Lakoff, 1973, p. 103). Limberg defines impoliteness as "an intentional form of face-aggravation" (Limberg, 2009, p. 1376); Bousfield explain it as "[...] an intentionally gratuitous strategy designed to attach face" (Bousfield, 2008, p. 132).

Several different approaches and definitions of the concept of emotion exist. Keinpointner (2008) notes that: "emotions can be defined as psycho-physical processes which are experienced as strong feelings" (Keinpointner, 2008, p. 246). In other words, readers might inferred if the speaker is being polite, therefore triggering a positive or pleasant emotion or impolite and rude generating a negative or unpleasant feeling.

Chang and Hsu's (1998) demonstrate that more than 50\% of the emails sent by Chinese learners of English to American native speakers were worded with the most direct strategies of want statement ("I want to hear your opinion"), imperatives and performatives.

Spencer-Oatey $(2005,2007)$ shows that "emotional reactions" of the speaker and addressee play a fundamental role in the negotiation of face concerns. Also, the emotional relationship between the interlocutors has a decisive role that might influence the cooperative or competitive climate of the ongoing interaction.

Culpeper establishes that "displaying emotions such as contempt or anger has nothing in itself to do with impoliteness" (Culpeper, 2011, p. 60). Power \& Dalgleish, 1997, p. 305) note that anger occurs "as the result of an appraisal of some deliberate, negligent, or at least avoidable slight or wrongdoing, [. . .] most usually directed at another person". Wierzbicka show that emotions can be triggered due to the "complex interaction between the components and subcomponents in culture-specific identities" (Wierzbicka 1994). That is, anger could be considered as a socio-moral emotion, arising in response to another's interlocutor violation of a social norm.

Anger ranges in intensity from mild irritation or annoyance to furious, animalistic, primordial rage. Therefore, it would be important to prevent the change of the status quo and maintain it within certain boundaries.

Different approaches to emotion have been analysed, researched and interpreted however, still 'there is little consensus on what emotion is or is not' (Barrett 1998, p. v, quoted in Schwarz-Friesel, 2007, p. 43).

(13) Dear xxx,

Many thanks for your quick reply

I am afraid you probably shall check out your emails, I've sent you email about the resit results before.

In the future, please remind the module leaders about the resits and hand it to me when you get the resit results. I cannot check on my side as to when the resit results come out and cannot request for results from you every time.

I think maybe you are not familiar with these above resit handing process, however I myself is not very familiar as well about Coventry's re-sit process. In the past, Xxx xxx just pass on me all the intensive modules' scores and then I put them into our SWUPL's score system. I've told xxx about our problems and maybe he can help with it or could you ask xxx xxx for some information about how the whole process is supposed to work? Best wishes,

Academic correspondence is directly related to written language; the sender lacks visual signals and context in order to monitor the recipient's reaction to their intended meaning. Example (10-12) show how the senders 'email might established a requester-requestee relationship. This also appears on (13):

"[...] you probably shall check out your emails, I've sent you email about the resit results before"

Moreover, (13) illustrates the possibility that Chinese learners of L2 English might inadvertently violate politeness norms by simply being clear in their statements

"[...] remind the module leaders about the resits and hand it to me when you get the resit results"

Likewise, clarity and minimum or no social distance and power between the interlocutors are used to minimize ambiguity:

"I think maybe you are not familiar with these above resit handing process $[\ldots]$ "

Example (13) shows that if the sender's correspondence were translated into Chinese, it would sound absolutely fine; the reader would have no reason to be offended. However, in English it sounds like a series of orders given by someone of very high rank. Thus, the emotion of mild irritation of the reader is visible in the readers' answers (14). In this case, the reader is less alert to cultural differences and misjudged the relevant behavior as impolite to a higher extent. That is, in (14) the reader might have inferred the sender's correspondence as FTAs.

Cross-cultural transferability of linguistics politeness might trigger the emotion of mild irritation in members of different speech communities who have already settled their specific types of conversational behavior

(14) Dear xxx

I will address your emails one at a time.

Firstly, I did not ask you to take the scores from the modules leaders.

The last thing you requested from me was the SWUPL Analysis Reports

Regards, $x x x$

(15) Hi xxx It's not proper for me to ask module leaders to give me the score, I think it's your job to collect all the 
re-sit results, convert into SWUPL scores and send back to me, that is the working process Coventry and SWUPL have set out in the beginning of our programme. You shall give me resit results of ELS, Land law, contract and US Legal system long time ago, but I haven't got them.

Best wishes, $\operatorname{xxxx}$

Example (14) shows that readers' individual inner mild sensation of anger has been precipitated by (13). However, the sender in (15) keeps maintaining a close and familiar relationship with the reader as identify in the salutation "Hi". (15) shows that positive politeness readers might not acknowledge the mild irritation triggered in negative politeness. In other words, Chinese L2 English learners do not find (14) offensive, rude or impolite.

It would be advisable for educators to include specific pragmatic contents for Chinese L2 English in order to minimize triggering mild irritations within negative politeness individuals.

Workshops on academic correspondence might help to prevent destabilizing personal relationships of interacting individuals. Moreover, it will decrease any mutual disrespect and/or aversion between the writer and the reader.

\section{ACADEMIC CORRESPONDENCE - ACTION RESEARCH}

Burns (2010) states: "[...] action research of the group is achieved through the critically examined action of individual group members" (Burns, 2010, p. 13); That is, action research focuses on bringing about change in social situation as the result of group problem-solving and collaboration. Moreover, Burns (2010) demonstrates in their survey, action research has made significant positive impacts in the discipline of English as Foreign Language. It helped teachers to reflect on their teaching strategies and to avoid issues they might face in their lectures.

That is, action research is an effective way of improving both the teaching and the students' performance. We do not advocate a change but an adaptation, in which learners might use strategies to understand a way of politeness that might be completely unfamiliar to them.

The common elements of action research are the four-step process ('Dialectic Action Research Spiral') in order to: a) identify an area of focus; b) collect data; c) analyze and interpret the data and d) develop an action plan. Figure 4 shows the action research plan we applied during the workshops.

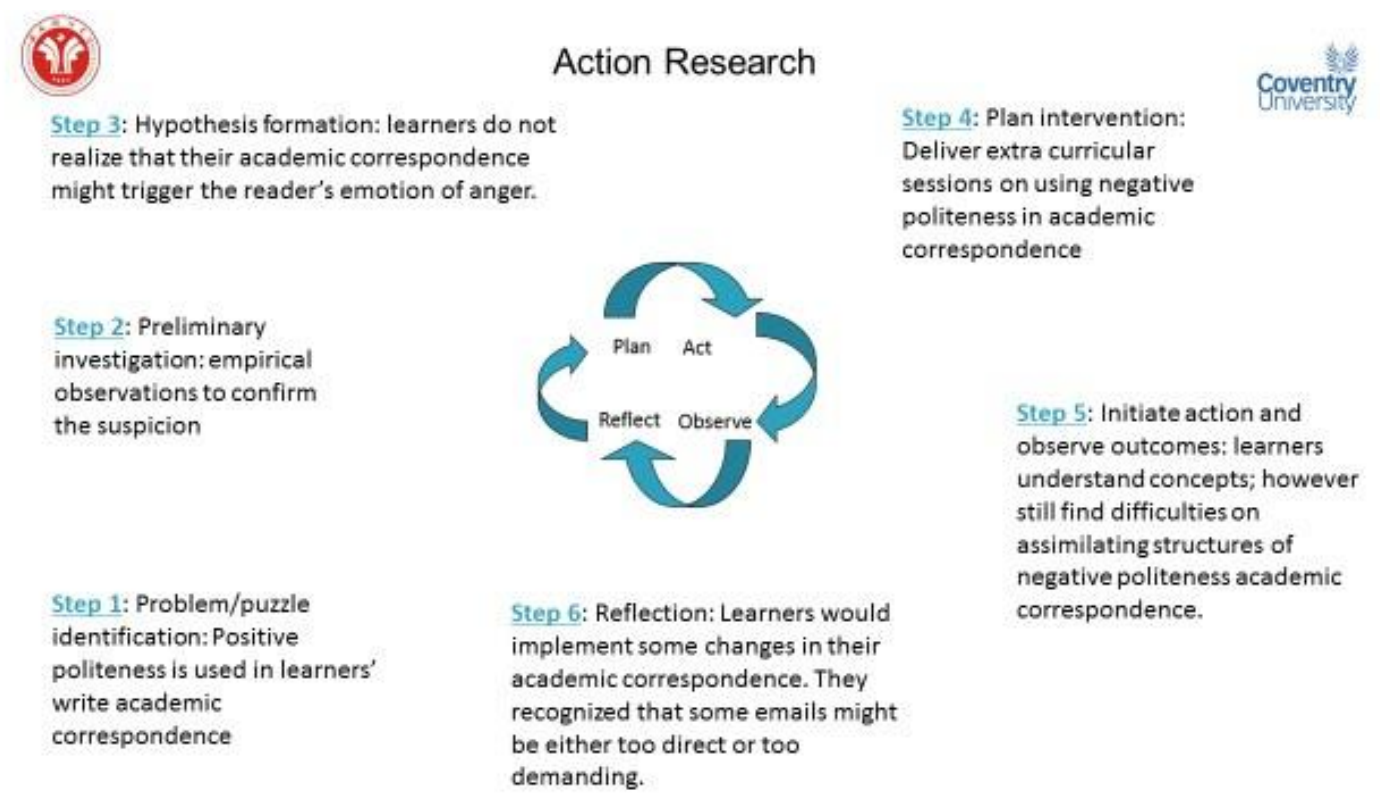

Fig. 4 The action research cycle

This follows the general objective of action research studies, which is designed to improve practice (Burns 2010) or as Kemmis \& McTaggart (1988) state "action research will lead to improvement evaluating the results of strategies in practice"; that is, action research is carried out by classroom practitioners; is collaborative in nature; and is aimed at bringing about change.

This study is based on a series of workshops, which are part of the programme's extracurricular activities; therefore, it was not compulsory to students to attend. However, attendance during the sessions was uniform between 17-20 students.

During the research, the cultural context was valued hence the author's sensitivity to the students' attitudes, views and needs were enhanced. Learners became deeply involved in their learning process however, the main challenge was to get students to write academic correspondence using negative politeness. The researcher's L1 is Spanish that is characterized by the use of positive politeness strategies in its linguistic structure (Escandell 1996, Alba De Diego, 
Vidal 1994; Alcón Soler \& Martínez-Flor 2008 and Haverkate 1984, among others) as it is also the case in Chinese; therefore the researcher could understand the transition from positive to negative politeness in academic correspondence.

Learners' academic correspondence via email or WeChat was clearly distinguished by the use of positive politeness; therefore, their content might have been inferred as demanding and/or imposing by negative politeness academics (Fig. 2).

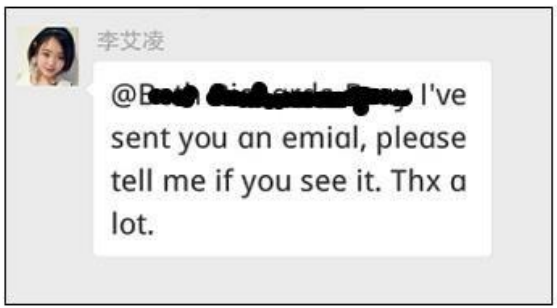

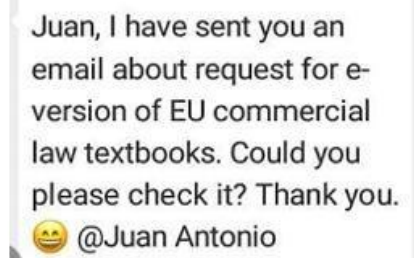
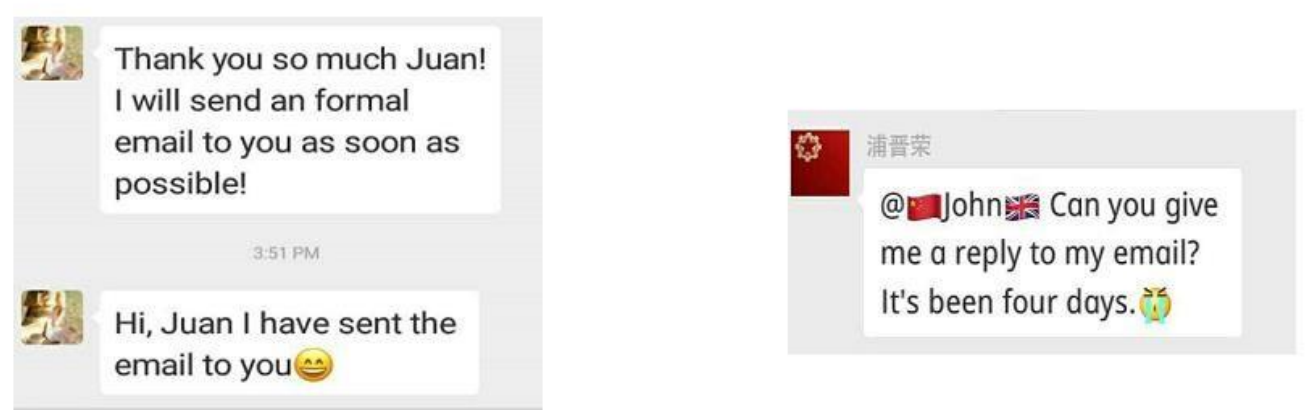

Fig. 5 Students' pressure on lecturers

Figure 5 shows how persistent students are in the communication with their lecturers. It also shows that the reader might have inferred "a remainder" as demanding and imposing; whereas learners might have implied the desire of having their wants considered, as Brown \& Levinson articulate on their definition of negative and positive face:

Negative face:

"The basic claim to territories, personal preserves, right to non-distraction / to freedom of action and freedom from imposition or the want of every competent adult member that his actions be unimpeded by others."

Positive face:

"The want of every member that his wants be desirable to at least some others." (Brown \& Levinson, 1987, p. 61)

The workshops focused on delivering specific pragmatic knowledge to help students to enhance using of negative politeness in their academic correspondence. Moreover, it was also suggested students to Cc me on their academic correspondence to other lecturers. The researcher started a "dialogue" with his students and decided to give both, general feedback during the sessions and individual feedback during office hours. The researcher tried to avoid the well-known "sandwich feedback" and instead attempted to elude negative politeness on the feedback given. During the feedback sessions, the researcher was acting as language enhancer through: a) ensuring learners have a true sense of their language needs and strengths; b) providing useful written and verbal feedback based on reducing the perception of FTAs by the readers; and c) creating opportunities for language practice. Both, workshops and feedback sessions, involved students to practice and enhancing their e-mails. Moreover, students were advice to take their time when writing an academic e-mail and most importantly, to read and re-read their writing before sending it out.

Students' responses were extremely surprising. They realised that academic correspondence is an important soft skill for employability purposes. Learners linked their degree with the extracurricular activity bridging them with their future career development. The workshops were not compulsory therefore, students did not have final written assignment.

In order to apply pedagogic approach to the exercises given, individual samples were used during the workshops. Through this initiative, students were able to do some peer revision and evaluation of their exercises. More importantly, all students were included in the opportunities of practicing writing throughout the teaching-learning process and the recognition of their efforts.

We used Open Moodle as academic tool. Students had, therefore, a solid platform to review, post, comment, practice and communicate with me and between themselves. Moreover, Open Moodle offered students the flexibility they needed in those cases where they were unable to attend the sessions.

The data collected generated from the evolution of the teaching and learning process. Most data were collected from original and authentic e-mails and WeChat academic correspondence. Students' comments on their feedback were also collected. Two mini teaching and learning surveys were conducted at the beginning and at the end of the sessions to 
monitor students understanding of their progress. By the end of the term, the data collection methods were triangulated. Data were collected from a number of different sources: conversations, learners' questions, emails, feedback, lecturers' feedback and opinions; therefore, increasing the reliability and validity of the research.

A case record was kept of the date collected for easy reference according to the following categories:

1. Class mini-surveys

2. Pre-workshop exercises

3. Students - lecturer informal conversations

4. Lecturers' emails to class

5. Students' emails to lecturers

6. Students' comments on workshop learning

The data provided a solid basis for me to acknowledge the students' learning progress and to evaluate the effectiveness of the research.

The findings strongly suggested that students were involved in their learning process. The data show that learners understood the principle of indirectness and ambiguity in academic writing correspondence. Students realized that their academic correspondence should show a trusting and mutual respect relationship between them and their lectures. This was important because it provided validity and justification for the extra-curricular workshops. It was noticed that students were continually practicing their academic correspondence writing. This continuous practice will also help them enhancing their language proficiency. According to the results of the initial survey, over $80 \%$ of the students expected to improve their academic writing skills; $86 \%$ of the students thought that their academic correspondence was polite; $92 \%$ that it was friendly; and $94 \%$ that it was clear. The survey showed that students' academic correspondence was dominated by positive politeness. At the end of the workshops the survey showed that over $95 \%$ of the students improved their correspondence language's skills; 91\% spent more time in the process of writing academic correspondence; 93\% re-read their writing before sending it out; and 95\% used some negative politeness strategies in their academic correspondence. However, students still find difficult and complicated to send professional academic correspondence without including positive politeness; lecturers could inferred it as demanding of imposing and therefore triggering a mild irritation of anger. (16) shows a clear example on how students' e-mails are still dominated by positive politeness and close, friendly relationship with the lecturer.

(16) Email about reference letter - See screenshot below.

\section{Email about the reference letter}

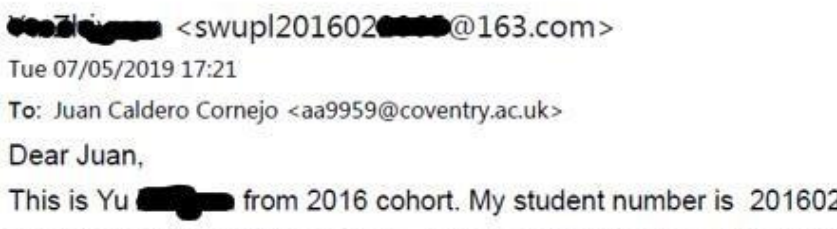

(16) illustrates students' difficulty in the process of adaptation from using of positive politeness to the alternative use of negative politeness. Students were encouraged to ask questions, to stimulate motivation and promote active learning. Individual queries were answered, clarified common misconceptions and kept the learning group informed of additional reading for better understanding of the sessions.

It is important to use the cycle of reflective research to bring about changes in own practice contributing to growing autonomy in the curricula. Although this action research was not as rigorous as other educational studies; A great sense of achievement was gained in guiding students in their academic correspondence writing.

Students' e-mails turned out to be of multiple varieties. Students focused on creative writing rather than academic 
writing (16). Students who were enrolled in the SINO-UK international programme should have had extra direct and succinct feedback from academics. Constructive criticism feedback would be important for both lectures and extracurricular sessions. This would have been another source of encouragement and motivation for students. At the end of the extra-curricular activity, the research surprised to find that learners' efforts where actively put in practice their learning. However, due to the nature of the extra-curricular sessions, students might not have been as motivated as the compulsory lectures and seminars of the programme.

\section{CONCLUSION}

To conclude, this study has found lack of awareness on politeness on learners' academic correspondence with the possible outcome of triggering of the emotion of mild irritation of the reader. The paper shows improvements on the understanding of students' use of negative politeness in their e-mails. However, (16) demonstrates that students still find difficult adapting themselves to the use of negative politeness strategies in their academic correspondence. Learners find certain degree of confusion and unawareness on the use of negative politeness in their academic correspondence.

Chinese learners of L2 English found that positive politeness is a respectful way to address their readers in the sense that learners are not considered lecturers but rather friends.

Most individuals are unfamiliar with the legal domain legal domain of speaking and writing. They would need language professional/linguistics to help them. That is, Chinese learners of L2 English are also unfamiliar using negative politeness in academic correspondence; these students could improve their communication skills attending session on pragmatics.

\section{REFERENCES}

[1] Alba De Diego, Vidal. (1994). La cortesía en las peticiones en Sánchez Lobato, J. y Santos Gargallo, I. (eds.) Problemas y métodos en la enseñanza del español como lengua extranjera. Actas del IV Congreso Internacional de ASELE, Madrid, SGEL, p. 413-425.

[2] Barrett, L.F. (1998). The Future of Emotion Research. The Affect Scientist 12 (2): 6-8.

[3] Biesenbach-Lucas. (2004). S. Speech acts in e-mail: a new look at pragmatic competence[R]. Portland: The Annual Convention of the American Association of Applied Linguistics.

[4] Bousfield, D. (2008). "Impoliteness in interaction". Amsterdam: John Benjamins Publishing.

[5] Félix-Brasdefer, C. (2012). Email requests to faculty: e-politeness and internal modification. In: Economidou-Kogetsidis, M., Woodfield, H. (Eds.), Interlanguage Request Modification. John Benjamins, Amsterdam, p. 87-118.

[6] Brown, P. and Levinson, S. (1987). Politeness: Some Universals in Language Usage. Cambridge University Press, Cambridge.

[7] Burns, A. (2010). Doing Action Research in English Language Teaching: A Guide for Practitioners. New York: Routledge.

[8] Chang, Yu-Ying, Hsu, Yi-Ping. (1998). Requests on email: a cross-cultural comparison. RELC Journal 29 (2), $121-151$.

[9] Conan Doyle, A. (2007). The adventures of Sherlock Holmes. London: Penguin Books

[10] Culpeper, J. (2012). Impoliteness: Three issues. Journal of Pragmatics, Vol. 44-9: 1128-1133

[11] Economidou-Kogetsidis, M. (2016). Variation in evaluations of the (im) politeness of emails from L2 learners and perceptions of the personality of their senders. Journal of Pragmatics 106 (2016) 1-19.

[12] Escandell, V. (1996). Towards a Cognitive Approach to Politeness, Contrastive Semantics and Pragmatics, Oxford, Pergamon Press: 629-650.

[13] Foster, S. (2013). How write better law essays: Tools and techniques for success in exams and assignments. Pearson. England.

[14] Grice, H.P. (1975). Logic and conversation. In: P. Cole and J.L. Morgan, Syntax and semantics, Vol. 3: Speech Acts, 41-58. London: Academic Press.

[15] Gumperz, J. (1982). Discourse Strategies. Cambridge, Cambridge University Press.

[16] Hartford, Beverly S., Bardovi-Harlig, Kathleen. (1996). 'At your earliest convenience': a study of written student requests to faculty. In: Bouton, L. (Ed.), Pragmatics and Language Learning, Volume 7. Urbana-Campaign: Division of English as an International Language. University of Illinois, pp. 55--69.

[17] Haverkate, H. (1984). Speech acts, speakers and hearers. Pragmatics \& Beyond V: 4. Amsterdam. John Benjamins.

[18] Kemmis, S., \& McTaggart, R. (1998). The Nature of Action Research. The Action Research Planner. Victoria: Deakin University.

[19] Kienpointner, M. (2008). Impoliteness and emotional arguments. Journal of Politeness Research 4: 243-265.

[20] Lakoff, R. (1973). The logic of politeness; or, minding your p's and q's. In: Papers from the 9th Regional Meeting of the Chicago Linguistic Society, pp. 292-305. Chicago Linguistic Society, Chicago.

[21] Leech, G. (1983). Principles of Pragmatics. London. Longman.

[22] Limberg, H. (2009). Impoliteness and threat responses, Journal of Pragmatics, 41: 1376-94.

[23] Locher, M.A. \& Bousfield D. (2008). Introduction: Impoliteness and power in language. In Bousfield \& Locher (eds.) Impoliteness in Language: Studies on its Interplay with Power in Theory and Practice. Berlin and New York: Mouton de Gruyter, pp. 1-13

[24] Mckernan, J. (1991a). Curriculum action research: A handbook of methods and resources for the reflective practitioner (pp. 1534). NY. St. Martin's Press Inc.

[25] Pan, Cathy. (2012). Interlanguage requests in institutional email discourse. In: Economidou-Kogetsidis, M., Woodfield, H. (Eds.), Interlanguage Request Modification. John Benjamins, Amsterdam, pp. 119-161.

[26] Power, M. and Dalgleish, T. (1997). Cognition and emotion: from order to disorder. Hove, East Sussex, UK: Psychology Press. 
[27] Snow, Catherine E., Perlmann, Rivka Y., Gleason, Jean B., Hooshyar, Nahid. (1990). North-Holland Developmental Perspectives on Politeness: Sources of Children's Knowledge. Journal of Pragmatics 14 (1990) 289-305.

[28] Spencer-Oatey, H. (2005). (Im)politeness, face and perceptions of rapport: unpackaging their bases and interrelationships. Journal of Politeness Research 1, 95-120.

[29] Spencer-Oatey, H. (2007). Theories of identity and the analysis of face. Journal of Pragmatics 39, 639-656.

[30] Spencer-Oatey, H., Ruhi, Sukriye. (2007). Identity perspectives on face and (im)politeness. Special issue of Journal of Pragmatics 39, 635-786.

[31] Wierzbicka, A. (1994). Cross-cultural pragmatics. The semantics of human interaction. Berlin and New York: Mounton de Gruyer.

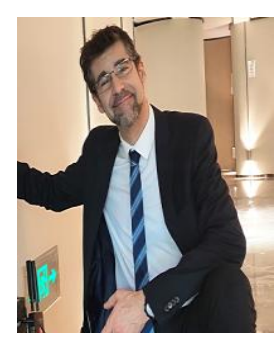

Juan Caldero was born in Madrid, Spain in 1971. He graduated with First-Class Degree in Political Science and Law at University Complutense in Madrid (Spain) in 1993. He has several Post-Graduate courses: MA in Diplomacy, Law and Global Change and MA in European Studies at Coventry University in Coventry (UK) in 1999/2000. MA in Teaching Second Language as Foreign Language at Alcala University in Madrid (Spain) in 2010. He successfully achieved his PhD in Education at University Complutense in Madrid (Spain) in 2016.

$\mathrm{He}$ is currently Lecturer in Legal English - English for Specific Purposes - in the in the School of Business and Law, Coventry University, Coventry, UK based at South West University of Political Science and Law in Chongqing, China since 2016

Previously, he taught different disciplines such as Language in the World, International Law, Pre-sessional English and Add-Vantage courses at Coventry University (UK). He has lectured at both undergraduate and postgraduate level at Coventry University, University of Warwick and University of Leicester.

Dr. Caldero research focuses on Politeness and Intercultural Communication; in particular face-threatening acts in requests. His research applies to modules such: linguistics and translation; first and second language acquisition; discourse analysis and language and the mind. Dr. Caldero has keen interest in Cooperative Online Learning (COIL) among academia.

Dr. Caldero is a member of the Erasmus Project Hook up! Language Learning Gateway (142782-LLP-1-2008-1-luerasmus-evc)

Dr. Caldero was awarded Higher Education Professional Practice at Coventry University (UK) in 2013 and Senior Fellow of the Higher Education Academy at Coventry University (UK) in 2020.

PUBLICATIONS:

Caldero Cornejo, J.A (2016) Percepción de la (des)cortesía de los actos exhortativos en la adquisición del español por dicentes de E/LE [https://eprints.ucm.es/id/eprint/40402/1/T38091.pdf]

Caldero Cornejo, J.A (2009) La cortesía en los actos de habla de especial importancia en el aprendizaje de E/LE. Universidad de Alcala - E-excelence [https://www.liceus.com/wp-content/uploads/2019/03/La-cortes\%c3\%ada-en-los-actos-de-habla-Aprendizajede-ELE-juan_antonio_caldero.pdf] ISBN: 978-84-692-8655-5

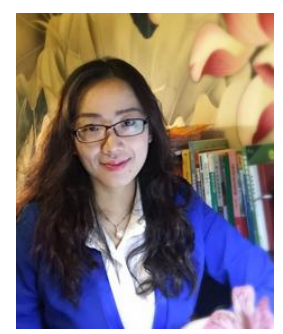

Lin Sun was born in Sichuan, China in 1983. She graduated with First-Class Degree in Xi'an Shiyou University majored in English in 2006, and obtained master degree in Southwest University of Political Science and Law in Forensic Linguistics in 2012, currently she is teaching while conducting doctoral research in Economic Law in Southwest University of Political Science and Law. The domain for her research is legal translation, language teaching and antitrust law.

PUBLICATIONS:

- Regulating the Drivers of On-line Car-Hailing in the Context of Sharing Economy, Venture Capital of China [J] (ISSN 1673-5811), 2016.Vol.12;

- Local Governments' Use of Covenants to Regulate Land Use, Research on Real Estate Law of China [J] (CSSCI, IF 1.67), 2017.Vol.15;

- Workplace Writings: Focus on Doing [M] (English version, editor for "Contract writing" part), China Renmin University Press, 2016

- Big Law [M] (trans., English to Chinese), Law Press of China, 2017;

- How to Argue and Win Every Time [M] (trans., English to Chinese), Law Press of China, 2017;

- Client Management for Lawyers [M] (trans., English to Chinese), Law Press of China, 2018;

- The Exclusionary Rule of Illegal Evidence in China [M] (trans., Chinese to English, Funded by Chinese Fund for the Humanity and Social Science), Springer, 2019;

- The Basic Issues Regarding Criminology Theory [M] (trans., Chinese to English, Funded by Chinese Fund for the Humanity and Social Science), Springer (forthcoming);

- The History of the Contractual Thoughts in Ancient China [M] (trans., Chinese to English, Funded by Chinese Fund for the Humanity and Social Science), Springer;

- Basic Contract Law [M] (trans., English to Chinese), China Legal Publishing House (forthcoming);

- Invited Speaker-“Court Interpretation of Criminal Cases: Empirical Studies in Chongqing”, Martin Centre's 3rd International Conference Appliable Linguistics and Legal Discourse, Shanghai Jiao Tong University 14th - 18th December 2016. 